\title{
Morphological Diversity and per se Performance in Upland Cotton (Gossypium hirsutum L.)
}

\author{
Kaliyaperumal Ashokkumar (Corresponding author) \\ Post Doctoral Fellow, Department of Plant Sciences \\ University of Saskatchewan \\ 51 Campus Drive, Saskatoon, S7N 5A8, SK, Canada \\ Tel: 1-306-881-1014 E-mail: biotech.ashok@gmail.com \\ Rajasekaran Ravikesavan \\ Cotton Breeding Station, Centre for Plant Breeding and Genetics \\ Tamil Nadu Agricultural University \\ Coimbatore-3, TN, India
}

Tel: 91-995-375-4711_E-mail: chithuragul@gmail.com

Received: October 20, $2010 \quad$ Accepted: November 12, 2010 doi:10.5539/jas.v3n2p107

This research was financed by Centre for Plant Breeding and Genetics, Cotton Breeding Station, Tamil Nadu Agricultural University, Coimbatore, India.

\begin{abstract}
A field experiment was conducted to find out the morphological diversity and per se performance of yield component traits, yield and a fibre quality traits eleven genotypes (four G. hirsutum cultivars viz., MCU 5, MCU 12, SURABHI and SVPR 2 and seven G. hirsutum genetic accessions viz., F 776, F 1861, SOCC 11, SOCC 17, TCH 1641, TCH 1644 and TCH 1646) during kharif 2005-06. Morphological traits of each genotype were measured on five randomly chosen plants in each replication. Significant differences were recorded for all the fourteen traits observed. The cultivar MCU 12 produced maximum yield ( $95.33 \mathrm{gm} / \mathrm{plant})$ due to more number of sympodia (24.17/ plant), number of bolls (25.17/plant), boll weight (4.20 g), ginning outturn (35.43\%), lint index $(6.12 \mathrm{~g})$ and seed index (10.44 g). Among the eleven genetic accessions, most of them expressed lowest value in yield and quality traits except SOCC17 superior in micronaire $\left(4.60 \mu \mathrm{g} / \mathrm{inch}^{-1}\right)$, SOCC11superior in fibre elongation (9.60\%) and TCH 1641 had high number of sympodia (28.97/plant) and number of seeds per boll (32). The cultivar SURABHI possess significantly more number of bolls (26.47/ plant), high ginning outturn (36.24\%), 2.5\% span length $(32.90 \mathrm{~mm})$ and bundle strength $\left(22.9 \mathrm{~g} / \mathrm{tex}^{-1}\right)$. The morphological traits data were used for assessing genetic diversity in the 11 cotton genotypes. NTSYS software was used to determine the genetic similarities and construct a dendrogram. The matrix of average taxonomic distance was estimated using Euclidian distance. The average taxonomic distance ranged from 0.1 to 1.4 . At a Euclidean distance of 0.8 , the 11 genotypes were grouped into IV clusters at $0.43 \%$ similarity level. Among the different clusters, the cluster size varied from one to four genotypes. The maximum number of genotypes was included in cluster I (four genotypes) and the minimum number in cluster II having only one genotype. The cluster III \& IV each had three genotypes. The analysis of variance revealed significant divergences among all the genotypes for all characters. In future, greater morphological diversity shown among the genotypes can be used to generate potential and promising hybrids.
\end{abstract}

Keywords: Cotton, Fibre quality traits, Morphological diversity, Per se performance and yield traits

\section{Introduction}

Cotton is the leading natural fibre crop and second most important oilseed crop in the world. It is an important cash crop of India being used in the textile industry and plays a key role in the national economy. However, the average productivity of cotton in India is the lowest among cotton growing nations of the world. The 
enhancement of productivity by developing high yielding varieties has always been a challenge to cotton breeders. In order to increase the yield potential, it is necessary to efficiently utilise the available genetic variability. The progress in the development of superior genotypes would depend upon the nature and magnitude of genetic variation present in the population. Currently, there is enormous need to further exploit the available genetic resources for greater benefits. Due to increase in the population growth rate, the demand for textile materials has also been steadily increased. Hence, efforts are needed to raise seed cotton yield through continuous selection of high yielding varieties and with broad range of adaptability to edaphic and climatic conditions and site specific varietal selection. The cultivars varied significantly for number of bolls per plant and lint index (Wang et al., 2004), ginning outturn and $2.5 \%$ span length (Khan et al., 1989) and seed cotton yield (Arshad et al., 2003; Ali et al., 2005; Sezener et al., 2006; Ehsan et al., 2008). Genetic diversity studies in cotton were accomplished earlier researchers (Lukonge et al., 2007; Khan et al., 2010). Consequently present study designated to explore the yield and fibre quality potential of accessions to evaluate the plant growth, yield component traits and fibre quality traits under the specific location. Studying morphological traits data for assessing genetic diversity in cotton genotypes is one of the major criteria for identification of genetic distances within the upland cotton. This will pave the way for the synthesis of superior parents for getting heterotically potential hybrid combinations.

\section{Materials and methods}

\subsection{Genetic material}

A field experiment was conducted to evaluate the growth, yield and fibre quality traits performance of four commercially cultivated varieties of cotton (Gossypium hirsutum L.) as viz., MCU 5, MCU 12, Surabhi and SVPR 2 and seven Gossypium hirsutum genetic accessions as viz., F 776, F 1861, SOCC 11, SOCC 17, TCH 1641, TCH 1644 and TCH 1646. The commercial cultivars were cultivated in southern states of India and genetic accessions were collected from Central Institute of Cotton Research, Coimbatore, in India.

\subsection{Experimental design and Field procedures}

The cotton cultivars and accessions were evaluated randomized block design (RBD) with three replications during Kharif 2005-2006 crop seasons at Cotton Breeding Station, Tamil Nadu Agricultural University, Coimbatore, and Tamil Nadu in India. Each genotype was grown in a 4.5 meter length row adopting a spacing of $75 \mathrm{~cm}$ between rows and $30 \mathrm{~cm}$ between the plants, so as to have 15 plants per row.

\subsection{Sampling, traits measurements and Methods}

Data were recorded on 5 randomly selected plants per replication for all the 14 characters viz., Plant height $(\mathrm{cm})$, number of sympodia per plant, number of bolls per plant, boll weight per plant (g), number of seeds per boll, seed cotton yield per plant $(\mathrm{g})$, ginning outturn $(\%)$, lint index $(\mathrm{g})$, seed index $(\mathrm{g}), 2.5 \%$ span length $(\mathrm{mm})$, fibre strength $(\mathrm{g} /$ tex $)$, micronaire value $(\mu \mathrm{g} / \mathrm{inch})$, uniformity ratio and fibre elongation (\%). Lint samples were submitted to Central Institute for Research on Cotton Technology unit at Coimbatore, Tamil Nadu (India) for analysis of fibre quality traits: $2.5 \%$ span length $(\mathrm{mm})$, Micronaire value $(\mu \mathrm{g} / \mathrm{inch})$, fibre strength $(\mathrm{g} / \mathrm{tex})$ and fibre elongation (\%).

\subsection{Statistical Analysis}

The mean values of the 14 characters measured in eleven genotypes in each replication were analyzed for estimation of Standard Error and Critical Difference by adopting the method suggested by Panse and Sukhatme (1964). The data on 14 morphological traits for all 11 genotypes were subjected to multivariate hierarchical cluster analysis using the computer software NTSYSpcv2.02i (Rohlf, 1998). The mean values were subjected to hierarchical cluster analysis performed by un-weighted pair-group arithmetic average method (Sneath and Sokal, 1973) using sequential agglomerative hierarchical nested cluster analysis (SHAN) programme. A phenetic tree was constructed using the TREEPLOT programme of NTSYS pc.

\section{Results and Discussion}

There was significant variation found for each trait in all the genotypes. The mean expression of the fourteen characters were recorded on the eleven genotypes (four cultivars MCU 5, MCU 12, Surabhi and SVPR 2 and seven genetic accessions F 776, F 1861, SOCC 11, SOCC 17, TCH 1641, TCH 1644 and TCH 1646) are presented in (Table 1 and 2). All the eleven cotton accessions differ significantly for plant height. The maximum plant height $(122.47 \mathrm{~cm})$ was observed in accession TCH 1646 and the lowest $(112.63 \mathrm{~cm})$ was observed in accession SOCC 17. Differences observed for plant height among cotton cultivars can be attributed to variation in genetic makeup of crop plants. These results are supported by the findings of Anwar et al. (2002) and Copur (2006) who also observed significant differences among cultivars for plant height. Data with regard to the 
number of sympodial branches per plant revealed a significant difference among cotton genotypes (Table 1 and Figure 1). The accession TCH 1614 produced the highest number of sympodia per plant (28.97). The lowest number of sympodia per plant was recorded by F776 (19.80). The difference in number of sympodial branches per plant can be attributed to differences in genetic makeup of the cultivars. The significant differences among varieties for number of sympodial branches per plant also have been reported by Copur (2006).

There was significant difference among the genotypes in case of number of bolls per plant. Significant and maximum number of bolls per plant was observed in cultivar SURABHI (26.47). The minimum number of bolls per plant was found in accession F776 (20.10). The mean number of bolls per plant in all the genotypes is 23.60 (Figure 1). The differences among cultivars for number of bolls per plant might have been due to the difference in genetic potential of the cultivars. The significant differences among varieties for number of bolls per plant had also been reported by Copur (2006) and Ehsan et al. (2008). Boll weight is directly related to the seed cotton yield of cotton. An evaluation of data indicated that greatest boll weight was recorded in cultivar MCU12 (4.20 g) and it was on par with cultivar MCU5 (4.14 g) and SVPR $2(4.12 \mathrm{~g})$ the lowest boll weight was recorded in accession TCH1644 (3.36 g). Significant differences were also found between SOCC11 (3.66 g), SOCC17 (3.92 g) and F776 (4.02 g). The mean boll weight of the all the genotypes is $3.92 \mathrm{~g}$ (Table 1). Significant differences among varieties for average boll weight had also been reported by Hofs et al. (2006). There was significant difference among the genotypes in case of number of seeds per boll. Maximum number of seeds per boll was observed in accession TCH1641 (32.00) which were significant. The minimum number of seeds per boll was found in accession TCH1644 (26.67). The average number of seeds per boll of the all the genotypes is 29.73 (Table 1). Significant differences were also found between MCU5 (28.43), SVPR2 (31.47) and SOCC17 (28.80).

All the cotton genotypes differed from each other for seed cotton yield per plant (Table 1 and Figure 1). The cultivar MCU 12 produced significantly higher seed cotton yield $(95.33 \mathrm{gm} /$ plant $)$ and lowest seed cotton yield was registered by the accession TCH $1644(59.50 \mathrm{gm} / \mathrm{plant})$. The mean yield of all the genotypes was 83.43 $\mathrm{gm} /$ plant. The maximum seed cotton yield with MCU 12 can be attributed to maximum number of sympodia per plant, number of bolls, boll weight, ginning outturn, lint index and seed index. These results are supported by the findings made by Hofs et al. (2006) and Copur (2006). Ginning out turn was significantly influenced by the genotypic differences. The highest value of ginning out turn was obtained in case of cultivar SURABHI (36.24 \%), but it was on par with cultivars SVPR 2 (35.80\%) and MCU12 (35.43\%). There is a positive relationship between yield and ginning out turn percentage. The lowest value of GOT was observed in case of cultivar SOCC $11(31.68 \%)$. These results are supported by Ehsan et al. (2008). There were significant differences in all the genotypes in case of lint index (g) and seed index (g) presented in (Table 2).

The comparison of treatment means indicated that cultivars had significant effect on fiber length. The highest $2.5 \%$ span length was recorded in case of cultivar SURABHI $(32.90 \mathrm{~mm})$ and the lowest $2.5 \%$ span length was found in accession SOCC $11(23.00 \mathrm{~mm})$. The mean 2.5\% span length was $28.15 \mathrm{~mm}$ (Table 2). Previous studies reported that fiber length could vary widely with plant variety and growing conditions. Ehsan et al. (2008), Copur (2006) and Khan et al. (1989) reported similar results for fiber length in cotton. The bundle strength was the lowest in $\left(18.9 \mathrm{~g} / \mathrm{tex}^{-1}\right) \mathrm{TCH} 1641$ and highest in $\left(22.9 \mathrm{~g} / \mathrm{tex}^{-1}\right)$ in SURABHI. The average bundle strength for all the genotype was $\left(20.66 \mathrm{~g} / \mathrm{tex}^{-1}\right)$. Fibre fineness or micronaire is very important characteristic concerning the fiber quality of cotton and is very useful for textile industry. The comparison of treatment mean indicated that cultivars varied significantly for fiber fineness. SURABHI had fine fibres $\left(3.4 \mu \mathrm{g}\right.$ inch $\left.^{-1}\right)$ SOCC17 registered coarse fibre $\left(4.6 \mu \mathrm{g} \mathrm{inch}{ }^{-1}\right)$. Differences between the cultivars with respect to fiber fineness were also found significant by Copur, (2006) and Ehsan et al. (2008). The range for uniformity ratio in cultivars was from 44 to 51, the genotypes exhibiting the values being Surabhi and MCU 5 respectively. The mean value for all the genotype was 48.36. The accession SOCC 11 posses significantly maximum fibre elongation $(9.6 \%)$ and minimum fibre elongation found in the accession TCH 1641 (5.8\%) as indicated in Table 2 and Figure 2. The mean fibre elongation in all the genotypes was 7.53 per cent.

The morphological traits data were used for assessing genetic diversity in the 11 cotton genotypes. Agglomerative hierarchical clustering performed on the Euclidean distance matrix utilizing the Ward's linkage method and resulting dendrogram is presented in (Figure 3). The average taxonomic distance ranged from 0.1 to 1.4. At a Euclidean distance of 0.8 , all the 11 genotypes were grouped into two major clusters which are having IV sub clusters at $0.43 \%$ similarity level. The list of all the 4 clusters along with the varieties included is presented (Table 3). Among the different clusters, the cluster size varied from 1 to 4 genotypes. The maximum number of genotypes were included in cluster I having 4 genotypes and the minimum number in cluster II having 1 genotype. The cluster I consisted of MCU 5, SURABHI, TCH 1646 and TCH 1644. The cluster II consisted of F 1861 only. The cluster III consisted of MCU 12, TCH 1644 and SVPR 2. The cluster IV consisted of F 776, 
SOCC 11 and SOCC 17. Earlier researchers (Lukonge et al., 2007; Khan et al., 2010) confirmed these similar results. Mahmood et al. 2006 suggested that intra-specific morphological diversity can further be exploited to acquire genetic information about traits in upland cotton.

\section{Conclusion}

On the basis of yield and yield components, the cultivar MCU 12 was found to be the best. The use of cultivar MCU 12 seems to be better to get maximum yield of cotton. The cultivar SURABHI possess significantly higher number of bolls, ginning outturn, 2.5\% span length and bundle strength, Surabhi may be used for developing high yielding cotton hybrids with high fibre length and strength. Apart from cultivars the genetic accessions possess low yield and yield components except SOCC11 which has superior fibre elongation and TCH 1641 had more number of sympodia and number of seeds per boll. SOCC17 was found superior in micronaire or fibre fineness, which is may be used to direct selection to release varieties for commercial cultivation for high fibre fineness. The genetic variability among the genotypes can be used to generate potential and promising hybrids.

\section{References}

Ali, Y., Aslam, Z., \& Hussain, F. (2005). Genotype and environment interaction effect on yield of cotton under naturally salt stress conditions. Int. J. of Environ. Sci. Tech., 2(2): 169-173.

Anwar, A. M., Gill, M.. I., Muhammad, D., \& Afzal, M. N. (2002). Evaluation of cotton varieties at different doses of nitrogen fertilizer. The Pak. Cottons, 46(1-4): 35-41.

Arshad, M., Afzal, M., Khan, M. I., \& Mahmood, R. (2003). Performances of newly developed cotton strains for economic and fiber traits in national coordinated varietal trials. Pakistan. J. of Scientific and Ind. Res., 46(5): 373-375.

Copur, O. (2006). Determination of yield and yield components of some cotton cultivars in semi arid conditions. Pak. J Biol. Sci., 9(14) 2572-2578.

Ehsan, F, Ali, A., Nadeem, Tahir, M.A., \& Majeed, A. (2008). Comparitive yield performance of new cultivars of cotton (Gossypium hirsutum L.). Pak. J. life and Soc.Sci., 6 (1):1-3.

Hofs, J. L., Hau, B., \& Marais, D. (2006). Boll distribution patterns in Bt and non-Bt cotton cultivars: I. Study on commercial irrigated farming systems in South Africa. Field Crops Res., 98(2 \& 3): 203-209.

Khan, W. S., Khan, A. A., Naz, A. S., \& Ali, S. (1989). Performance of six Punjab commercial varieties of Gossypium hirsutum L. under Faisalabad conditions. The Pak. Cottons, 33(2): 60-65.

Khan, A.I., Awan, F. S., Sadia, B., Rana, R. M., \& Khan, I. A. (2010). Genetic diversity studies among coloured cotton genotypes by using RAPD markers. Pak. J. Bot., 42(1): 71-77.

Lounge, E., Herselman,L., \& Labuschange, L. T. (2007). Genetic diversity of Tanzanian cotton (Gossypium hirsutum L.) revealed by AFLP analysis. African Crop Science Conference Proceedings. 8: 773-776.

Mahmood, S., Irfan, M., Raheel F., \& Hussaim, A. (2006). Characterization of cotton (Gossypium hirsutum L.) varieties growth and productivity traits under water deficit conditions. Int. J. Agri. Biol., 8(6):796-800.

Panse, V.G., \& Sukhatme, P.V. (1964). Statistical Methods for Agricultural workers 2nd Ed., ICAR publishing, New Delhi. pp1-361.

Rohlf, F. J. (1998). NTSYS-pc. Numerical taxonomy and multivariate analysis system, version 2.02. Exter Software, Setauket, NY.

Sezener, V., Bozbek, T., Unay, A., \& Yavas, I. (2006). Evaluation of cotton yield trials under Mediterranean conditions in Turky. Asian J. of Plant Sci., 5(4): 686-689.

Sneath, P. H. A., \& Sokal, R. R. (1973). Numerical Taxonomy. Freeman San Francisco. pp1-573.

Wang, C., Isoda, A., \& Wang, P. (2004). Growth and yield performance of some cotton cultivars in Xinjiang, China, an arid area with short growing period. J. Agron. Crop Sci., 190 (3): 177-183. 
Table 1. Mean expression of yield components and seed cotton yield in 11 cotton genotypes

\begin{tabular}{|l|c|c|c|c|c|c|}
\hline Characters & $\begin{array}{c}\text { Plant } \\
\text { Height } \\
(\mathrm{cm})\end{array}$ & $\begin{array}{c}\text { Number of } \\
\text { sympodia /plant }\end{array}$ & $\begin{array}{c}\text { Number of bolls } \\
\text { per plant }\end{array}$ & $\begin{array}{c}\text { Boll weight } \\
\text { /boll }\end{array}$ & $\begin{array}{c}\text { Number of seeds } \\
\text { per boll }\end{array}$ & $\begin{array}{c}\text { Seed cotton } \\
\text { Yield } \\
\text { (gm/plant) }\end{array}$ \\
\hline Cultivars & & & & & & \\
\hline MCU 5 & 121.53 & 24.97 & 24.07 & 4.14 & 28.43 & 86.93 \\
\hline MCU 12 & 120.43 & 24.13 & 25.17 & 4.20 & 28.80 & 95.33 \\
\hline SURABHI & 121.63 & 24.17 & 26.47 & 3.96 & 29.33 & 88.13 \\
\hline SVPR 2 & 120.87 & 20.07 & 23.83 & 4.12 & 31.47 & 91.03 \\
\hline Accessions & & & & & & \\
\hline F 776 & 121.37 & 19.80 & 20.10 & 4.02 & 30.58 & 78.70 \\
\hline F 1861 & 122.43 & 21.88 & 25.03 & 4.00 & 31.47 & 87.80 \\
\hline SOCC 11 & 120.97 & 23.53 & 24.20 & 3.66 & 30.13 & 77.33 \\
\hline SOCC 17 & 113.63 & 19.90 & 24.80 & 3.92 & 28.80 & 80.03 \\
\hline TCH 1641 & 121.10 & 28.97 & 22.10 & 3.90 & 32.00 & 79.47 \\
\hline TCH 1644 & 121.37 & 24.13 & 21.57 & 3.36 & 26.67 & 59.40 \\
\hline TCH 1646 & 122.47 & 22.07 & 22.27 & 3.85 & 29.33 & 93.57 \\
\hline Mean & 120.71 & 22.32 & 23.60 & 3.92 & 29.73 & 83.43 \\
\hline SE & 1.4678 & 0.9836 & 1.0911 & 0.1534 & 0.7805 & 2.883 \\
\hline $\begin{array}{l}\text { CD 5 \% } \\
\text { level }\end{array}$ & 4.1101 & 2.7542 & 3.0552 & 0.4295 & 2.1856 & 4.0847 \\
\hline
\end{tabular}

Table 2. Mean expression of seed traits and fibre quality traits in 11 cotton genotypes

\begin{tabular}{|l|c|c|c|c|c|c|c|c|}
\hline Characters & $\begin{array}{c}\text { Ginning } \\
\text { Outturn } \\
(\%)\end{array}$ & $\begin{array}{c}\text { Lint } \\
\text { Index } \\
(\mathrm{g})\end{array}$ & $\begin{array}{c}\text { Seed } \\
\text { index } \\
(\mathrm{g})\end{array}$ & $\begin{array}{c}2.5 \% \\
\text { Span } \\
\text { length } \\
(\mathrm{mm})\end{array}$ & $\begin{array}{c}\text { Bundle } \\
\text { strength } \\
\left(\mathrm{g} / \mathrm{tex}^{-1}\right)\end{array}$ & $\begin{array}{c}\text { Micronaire } \\
\left(\mu \mathrm{g} / \mathrm{inch}^{-1}\right)\end{array}$ & $\begin{array}{c}\text { Fniformity } \\
\text { Ratio }\end{array}$ & $\begin{array}{c}\text { Percentage } \\
\text { elongation } \\
(\%)\end{array}$ \\
\hline $\begin{array}{l}\text { Cultivars } \\
\text { MCU 5 }\end{array}$ & 34.92 & 5.74 & 10.09 & 28.3 & 20.1 & 4.3 & 51 & 6.9 \\
\hline MCU 12 & 35.43 & 6.12 & 10.44 & 29.6 & 22.2 & 4.1 & 49 & 6.8 \\
\hline SURABHI & 36.24 & 5.36 & 9.20 & 32.9 & 22.9 & 3.4 & 44 & 6.9 \\
\hline SVPR 2 & 35.80 & 5.47 & 8.87 & 28.9 & 19.8 & 4.3 & 49 & 8.5 \\
\hline Accessions & 33.85 & 5.78 & 11.11 & 27.5 & 21.8 & 3.7 & 50 & 8.1 \\
\hline F 776 & 34.01 & 4.78 & 8.05 & 28.4 & 21.1 & 3.4 & 48 & 7.4 \\
\hline F 1861 & 31.68 & 3.93 & 8.46 & 23.0 & 20.7 & 4.3 & 50 & 9.6 \\
\hline SOCC 11 & 33.68 & 4.76 & 8.55 & 24.5 & 20.0 & 4.6 & 50 & 8.6 \\
\hline SOCC 17 & 32.46 & 4.62 & 9.62 & 29.1 & 18.9 & 4.2 & 44 & 5.8 \\
\hline TCH 1641 & 33.16 & 4.20 & 8.48 & 28.3 & 19.7 & 4.0 & 49 & 7.6 \\
\hline TCH 1644 & 32.75 & 4.31 & 8.84 & 29.1 & 20.1 & 4.0 & 48 & 6.6 \\
\hline TCH 1646 & 34.00 & 5.10 & 9.25 & 28.15 & 20.66 & 4.0 & 48.36 & 7.53 \\
\hline $\begin{array}{l}\text { Mean of } \\
\text { Genotypes }\end{array}$ & & & & & & & & \\
\hline SE & 0.79 & 0.31 & 0.61 & 0.24 & 0.25 & 0.16 & 0.43 & 0.21 \\
\hline $\begin{array}{l}\text { CD 5\% } \\
\text { level }\end{array}$ & 2.21 & 0.88 & 1.72 & 0.69 & 0.35 & 0.46 & 1.20 & 0.61 \\
\hline
\end{tabular}


Table 3. Cluster composition of Gossypium hirsutum genotypes classified by morphological characters

\begin{tabular}{|c|c|l|}
\hline $\begin{array}{c}\text { Cluster } \\
\text { No. }\end{array}$ & $\begin{array}{c}\text { Number of } \\
\text { varieties }\end{array}$ & Number of genotypes included \\
\hline I & 4 & $\begin{array}{l}\text { MCU 5, SURABHI, TCH 1646 and } \\
\text { TCH 1644 }\end{array}$ \\
II & 1 & F 1861 \\
III & 3 & MCU 12, TCH 1644 and SVPR 2 \\
IV & 3 & F 776, SOCC 11 and SOCC 17 \\
\end{tabular}

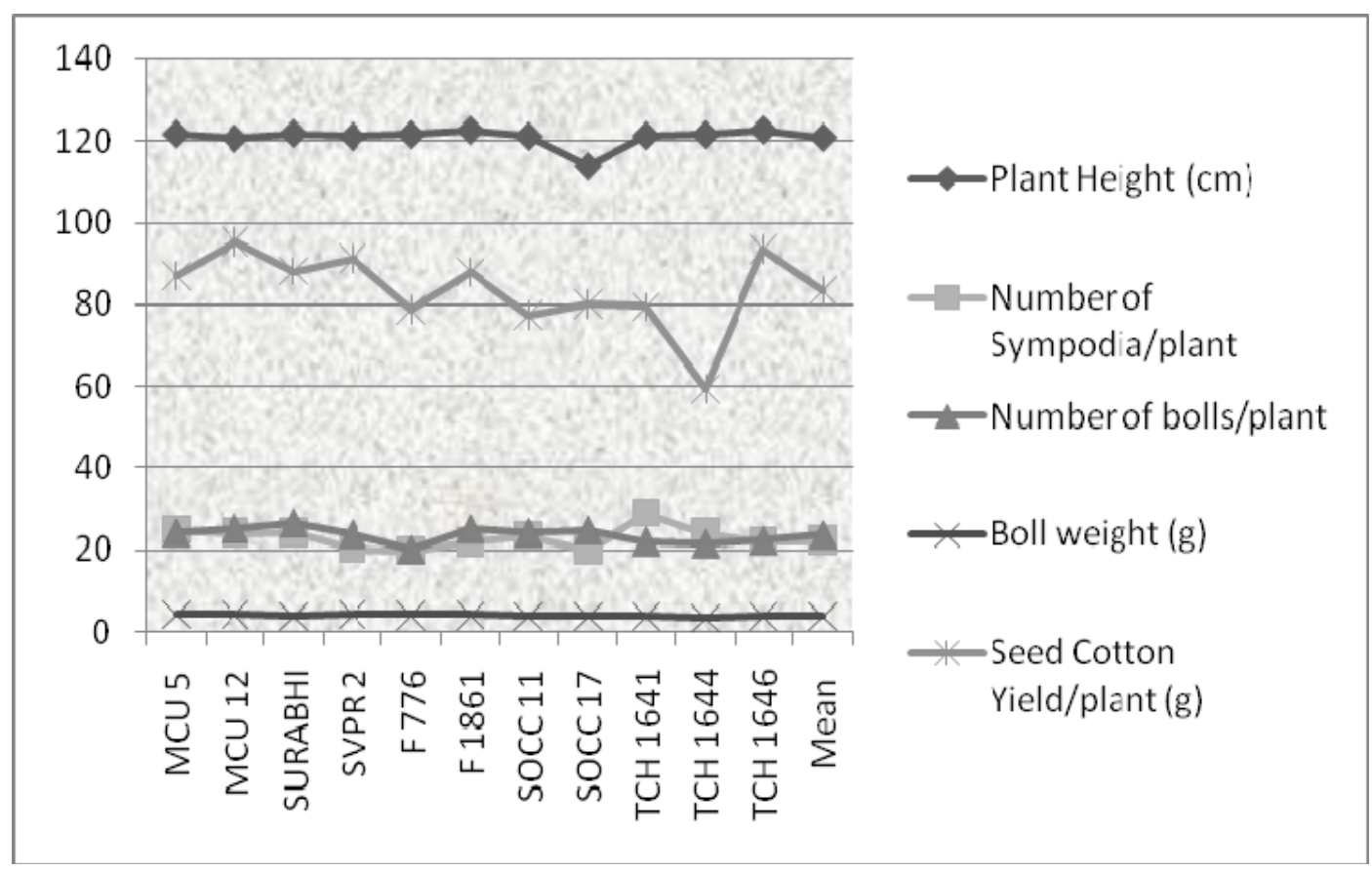

Figure 1. Per se performance of Seed cotton yield and yield component traits in upland cotton genotypes 


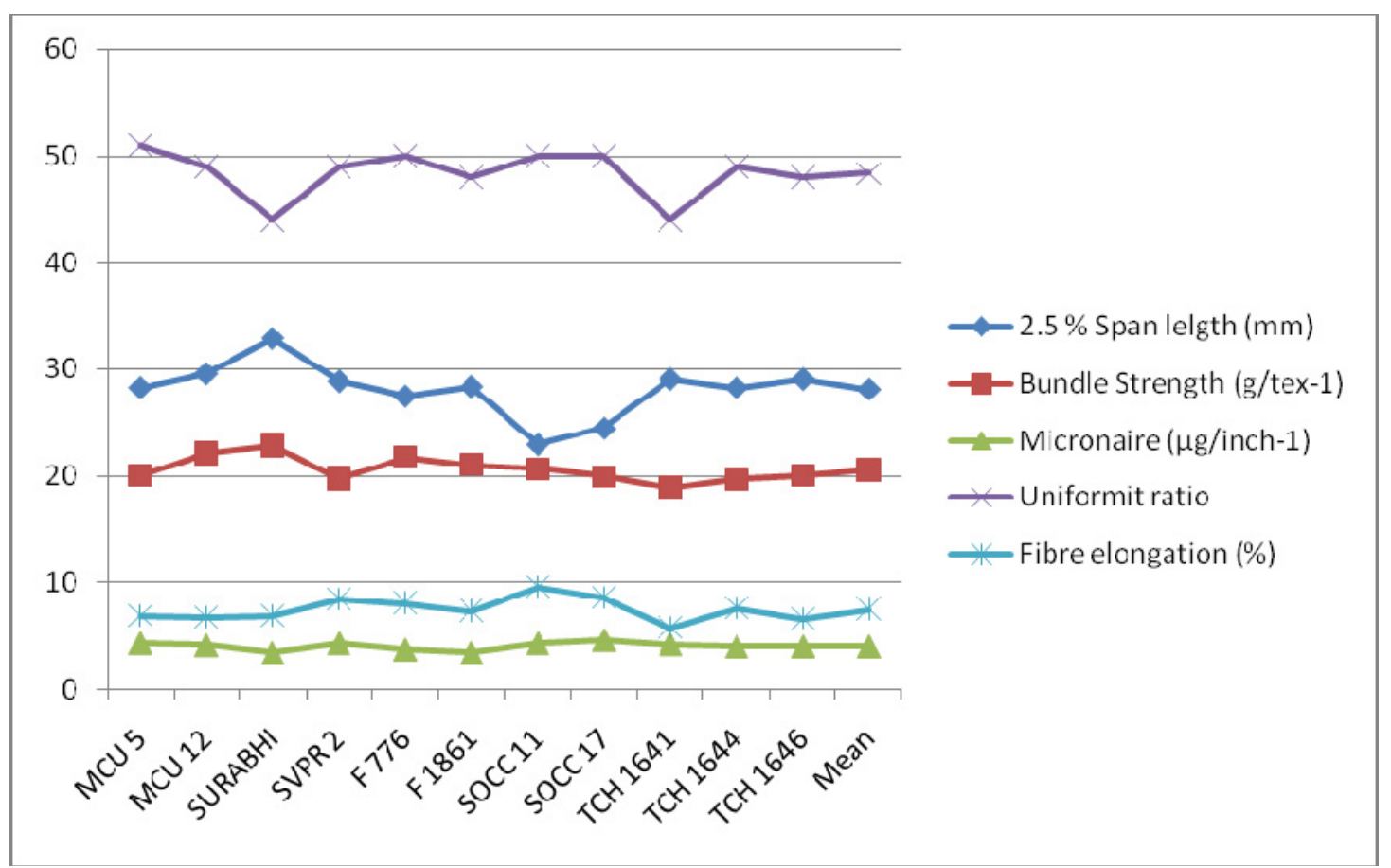

Figure 2. Per se performance for fibre quality traits in upland cotton genotypes

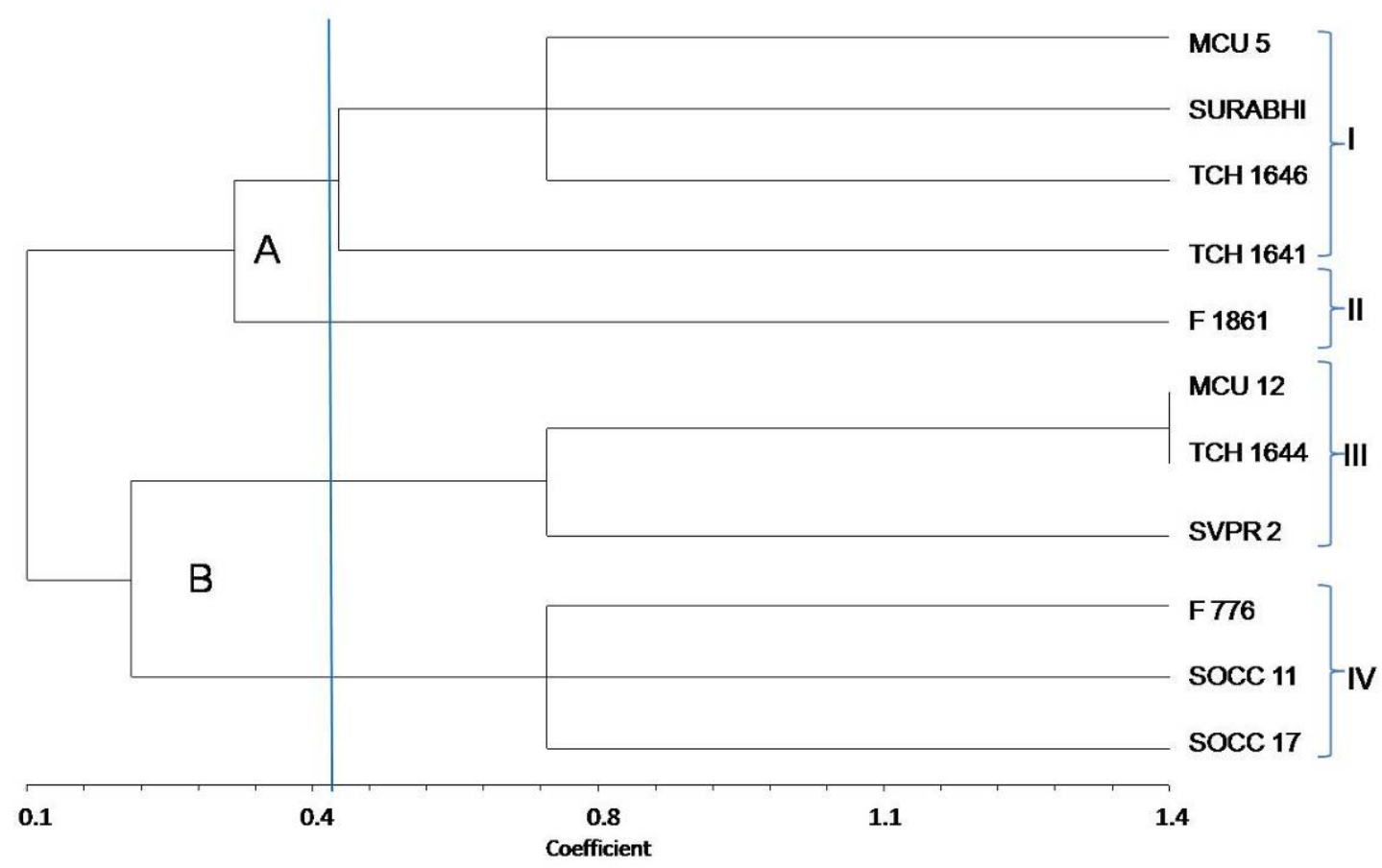

Figure 3. Cluster diagram for 11 upland cotton genotypes classified by 14 agronomic characters 